\title{
INSTITUTIONAL VS. SECTORAL DIMENSION OF INNOVATION STRATEGIES OF FIRMS
}

\author{
Inga STANKEVICEa, Giedrius JUCEVICIUS ${ }^{\mathrm{b}}$ \\ ${ }^{a}$ Nottingham University Business School, University of Nottingham, \\ Jubilee Campus, NG8 1BB, Nottingham, United Kingdom \\ ${ }^{\mathrm{a}, \mathrm{b}}$ Department of Strategic Management, Kaunas University of Technology, \\ Donelaičio g. 20, 44239 Kaunas, Lithuania
}

Received 08 April 2012; 22 June 2013

\begin{abstract}
In light of the controversy of the dispute about the role of national institutions in shaping innovation strategies of firms, and in light of the lack of explicitness of the notion of innovation strategy within the dispute, this paper aims at ascertaining if national institutional subjection of a firm is fateful in shaping its innovation strategy. The sample companies represented two distinct sets of institutions - Lithuanian vs. Swiss, and two distinct sectors - laser producers vs. contact centres. Warm-house conditions were ensured to eliminate other potentially disruptive factors. Following methods were used to analyse the data: exploratory case study, correlation analysis, test of difference, cluster analysis, and cross-tabulation. The survey highlighted the most important, with regard to national and sectoral disparities, characteristics of innovation strategy.
\end{abstract}

Keywords: innovation strategy, institutional environment, sectoral environment, Lithuania, Switzerland, laser producer, contact centre.

Reference to this paper should be made as follows: Stankevice, I.; Jucevicius, G. 2013. Institutional vs. sectoral dimension of innovation strategies of firms, Technological and Economic Development of Economy 19(Supplement 1): S360-S382.

JEL Classification: L14, L21, L23, O14, O31, O32, P52.

\section{Introduction}

It might be true that, in countries which have experienced relatively recent large-scale changes, despite initial eagerness to adopt new institutional frameworks and ways of management, the potential for an adverse reaction is strong. For example, the former regime in Eastern Europe served to reduce uncertainty; however, this experience, according to Schneider and

Corresponding author Inga Stankevice

E-mail: lixis6@nottingham.ac.uk,inga.stankevice@ktu.edu 
Barsoux (2003), "created a sense of learned helplessness, a sense of being unable to make an impact, as well as a strong fear of making mistakes". If so, national institutions in Eastern Europe can easily become scapegoats on which low rates of innovativeness and poor ability of facilitating competitive innovation strategies are blamed.

However, there are a number of indirect scientific arguments and evidence both for and against the idea that national institutional environment (NIE) is a decisive factor determining the character of innovation strategy of a firm originating from and operating largely in that environment. For instance, the key assumption of the varieties of capitalism approach (Hall, Soskice 2001) is the comparative institutional advantage (CIA). It implies that firms focus on innovation strategies that are supported by the dominant national institutional framework (Casper 2009). A clear example of that are Whitley's (2000) five different innovation strategies which are most likely to appear in certain market economies. According to the institutionalisation theory (Lewin, Volberda 2005), environments with dominating technical and economic demands favour radical innovations, whereas environments with dominating social demands foster incremental ones. The approach of national systems of innovation (Lundvall 1992) confirms the idea of CIA, though it is more specialized in respect of industrial sectors (Amable 2000). The notions of regional innovation systems (Doloureux 2002) and other geographies of production, such as industrial districts, innovative milieus, new industrial spaces and clusters (Malakauskaite, Navickas 2011), are allied to those of varieties of capitalism and national systems of innovation because they not only emphasize that the core of production is still heavily concentrated in particular regions and that globalization does not necessarily lead to de-territorialisation, but support the assumption that local capabilities are, to some extent, always dependent on national opportunities (Fromhold-Eisebith 2007). Other scholars support the paradigm of CIA by stressing its importance to factors which are closely related to innovation strategies: entrepreneurship (Hall, Sobel 2008), competitiveness and innovativeness (Koen 2005). The ideas are supplemented by Thomsen's (2008) research in transition and post-transition economies. In general, admittance of the idea of CIA leads to a conclusion that innovation strategy is "path dependent, locally embedded and institutionally shaped" (Köhler 2008).

In the other camp, the concept of CIA is seriously questioned. Lange (2009) states that institutional heterogeneity (Allen 2004; Schneiberg 2007) and trans-nationalisation (Fuller 2009) are two pivotal challenges to the notion of varieties of capitalism. Market economies are characterized by institutional heterogeneity and relative openness, which means that firms can make their innovation strategies competitive by relying on inputs provided by alternative institutions, be they domestic or part of foreign business systems (Lange 2009). Lane (2008), in view of global production and innovation networks, argues that, under the impact of global markets, the notions of national institutional reproduction and CIA need to be re-conceptualized to reflect the complexity of global effects. Similarly, Amable (2000) suggests that the approach of social systems of innovation is preferable due to its indifference to the question of a territory over which the gamut of inter-organizational and inter-institutional networks operates. Furthermore, Herrmann (2008) illustrates that firms do not inevitably get mileage out of CIAs: they can also bypass institutional constraints. It might even be purposive for firms to circumvent institutional restraints because governments, under certain circumstances, can block innovation and suppress growth (Chaudhry, Garner 2007). 
Hence, one might conclude that the assumption about the subjection of firms' innovation strategies to national institutions, which they are supposed to be embedded within, can be regarded to as a dangerously widespread fallacy.

However, the problem addressed in this paper arises from not solely the debate over the significance of national institutions to firms and their innovation strategies. Today, it is increasingly difficult to clearly distinguish the concept of innovation strategy because the existing variety of attitudes towards both innovation and strategy has unfortunately led to a lack of scrutiny in using the term. Accordingly, the debate introduced above over-interrelates the impact of institutional environment on innovation strategies with its impact on, for example, general management strategy (Herrmann 2008), or competitiveness and success (Casper 2009), or innovativeness (Fromhold-Eisebith 2007), or processes by which organizations gather and interpret information about strategic issues, etc. thus making the comprehension of the interaction between national institutional context and corresponding firms' innovation strategies even more vague and fragile.

In light of the controversy of the debate about the role of national institutional environment in shaping firms' innovation strategies, and in light of the lack of explicitness of the notion of innovation strategy within the debate, this paper aims at ascertaining if national institutional environment is the most decisive factor determining the character of innovation strategy of a firm originating in that particular national institutional environment. In addition to literature review regarding the delineation of the concepts of national institutional environment and innovation strategy, the research methodology rests on the application of the refined integrated theoretical framework of innovation strategy to an exploratory research of four companies. The companies represent an intersection of two distinct sectors and two distinct sets of national institutions. Special warm-house conditions were ensured in order to highlight results of this intersection. Both qualitative and quantitative methods were used to analyse the data. Finally, conclusions are drawn.

\section{Brief delineation of main concepts}

\subsection{National institutional environment}

\subsubsection{Conceptual delineation}

At least two kinds of institutions can be distinguished (Rolfstam 2009): first, formal institutions at the economic, legal and political level; second, informal institutions, ingrained in the social and cultural area. However, there is no explicit agreement on which institutions are more important than others for factors related to innovation strategy (e.g. prosperity, growth, entrepreneurship), or which institutions do or do not belong to national systems of innovation (Hollingsworth 2000). Though some scholars (Acemoglu, Robinson 2010) insist that the main determinants of differences in prosperity, long-run technological progress, and innovativeness across countries are differences in economic and political institutions, others (Redding 2005) argue that social and cultural dimensions within the institutionalist literature have long been neglected or even ignored, and advocate a multidisciplinary approach towards institutional environment surrounding innovations. 
Hence, the arguments and findings mentioned above make this paper confined to a broad understanding of institutional environment, which encompasses a number of dimensions of national institutional environment, and regardless of their level of (in-) formality. Institutional Profiles Database allows for a structured and professional comparison of national institutional contexts. The Database 2009 (Crombrugghe et al. 2009) covers 123 countries, including Lithuania and Switzerland, and contains 368 indicators for a wide range of institutional characteristics. These are broken down into nine institutional functions: 1) Political institutions; 2) Safety, Law and order, Control of violence; 3) Functioning of public administrations; 4) Free operation of markets; 5) Coordination of actors, Strategic vision, Innovation; 6) Security of transactions and contracts; 7) Market regulations, Social dialogue; 8) Openness to the outside world; and 9) Social cohesion and mobility. The nine institutional functions are then crossed with four sectors: A) Public institutions and civil society; B) Market for goods and services; C) Capital market; D) Labour market and social relations. Thus, the Institutional Profiles Database 2009 relies on a broad definition of institutions, both formal and informal, and a non-normative approach (Crombrugghe et al. 2009). This is also the case of this paper.

\subsubsection{Innovation strategy from different angles of institutionalist literature}

The approach of varieties of capitalism (VoC) has largely been criticized for its unreliability in predicting firms' innovativeness (Lane 2008; Lange 2009), despite the fact that the opponent statements have not been silenced (Casper 2009). Though Hall and Soskice (2001) define institutions as a set of formal and informal rules, which are predominantly followed by actors for normative, cognitive or material reasons, they are not consistent enough, for further they rely on regulative institutions and rules, which actors follow for material reasons only (Lange 2009). For the authors, the institutions are comprised of financial, industrial relations, education and training, and intercompany systems, which form either type of economy - liberal market economy or coordinated market economy. The former enables short-term relations and market-based coordination, so it is conducive to radical innovations, whereas the latter promotes long-term relations and coordination, based on non-market mechanisms, and therefore, coordinated market economy fosters incremental innovations.

Similar distinction is identified by the proponents of institutionalization theory: environments with dominating technical and economic demands favour effectiveness and novelty, and are conducive to radical innovations; contrarily, environments with dominating social demands favour organizations for an endorsement of values, rules, trust and, consequently, incremental innovations (Lewin, Volberda 2005). However, the dichotomy does not explain innovativeness of a great variety of intermediate economies. Moreover, there is evidence that Germany, which was considered a typical coordinated economy, is characterized by heterogeneous institutions, which tolerate strategic leeway of firms (Lange 2009); and in the United States, which stood for a model liberal market economy, many radically innovative sectors have become such due to precisely public investment (Lane 2008).

Another related approach is that of national systems of innovations (NSI) (Lundvall 1992). Here, a spectrum of understandings of institutions is distinguished: from the narrow one, which includes science, research, technology, and sometimes education, to the broad one, which encompasses all institutions that affect production and innovation (Amable 2000). 
There are several weaknesses of the approach: first, differently from the varieties of capitalism, it does not imply institutional complementarity; second, most of the studies concern one country at a time; third, when international comparisons are made, they are limited to a small number of sectors. Within the frames of namely NSI, the most of the contributions to the debate, revealed in the introductory part of the paper, emerged. Thus, it is difficult to identify any rigid patterns of institutional or sectoral embeddedness of innovation strategies of firms within this approach, as the fragmented research lead to fragmented results. What unites the proponents of the approach is the recognition of the importance of science, research, technology and education to innovativeness, and, to a lesser extent, to a choice of innovation strategy.

While the approach of national systems of innovation is too fragmented, that of social systems of production is criticized for its overall comprehension of institutions, which disarms empirical research. Whitley (2000) attempted to integrate the three approaches by introducing five types of innovation strategies. Dependent innovation strategies organize relatively well-known product qualities within widely understood frameworks, they rarely involve the development of radically new elements, and goods and services from current and closely related components are combined and targeted to specific user groups. The strategies are typical to firms that focus on flexibility and manage market uncertainty by rapid adjustments to change. These firms do not need to develop long-term organizational capabilities, therefore, dependent innovation strategies tend to appear in countries with low state coordination, weak intermediary associations and unions, and limited trust in formal institutions. On the contrary, complex, risky innovation strategies involve developing new product qualities that have a wide range of uses and may lead to market restructuring as previous products become obsolete. Firms developing these strategies seek to dominate markets by introducing new products, and a wide variety of sources are usually necessary. Hence, the firms are often encouraged to cooperate with local associations, unions, colleges, etc. and risky innovation strategies are most likely to survive in environments with considerable state coordination, pretty strong labour unions, and credit-based financial systems.

Similarly, Whitley (2000) describes the relationship between national institutional environment and the remaining three innovation strategies. However, his arguments are contradictory to some extent. On the one hand, he states that different firms pursue the distinguished innovation strategies to varying degrees in different institutional contexts, and this leads to variation in innovative performance. On the other hand, the innovation strategies are associated with concrete business systems, which develop in particular institutional contexts, meaning that a certain institutional configuration is not that likely to support variation of firms' innovation strategies. One might object to the critics by pointing to that the two sides of the contradiction concern different levels in the argumentation (i.e. institutional context and business system). However, the argumentation concerns the same level - the institutional one. In other words, when the relationship between innovation strategy and institutional environment is considered straightforward (i.e. the "black box" is blank), firms pursue different innovation strategies to varying degrees in different institutional contexts, and the variation is accepted. On the other side, when the "black box" contains business systems, the variation is denied, as a certain institutional setting supports a certain type of business system, and a 
certain type of business system supports a certain type of innovation strategy. Can the same institutional setting include different business systems? Whitley (2000) answers dubiously positively, thus supporting the statement about the varied innovation strategy. Still, the author's (Whitley 2000) model is not supportive of the existence of different business systems within the same institutional context, and thus, the positive answer is more a proviso than a part of the developed model.

Amable (2000) pursued to overcome the drawbacks of the presented approaches as well. He distinguished four types of social systems of innovation and production (SSIP) in accordance with the interplay of six sub-systems: science, technology, industry, labour force, education and training, and finance. Each of the four types imposes certain consequences for products, innovations and industrial specialization. For instance, social-democratic SSIP, which is characterized by bargaining between social partners, importance of social needs in the definition of research objectives, egalitarian ideals, centralization of wage bargaining under the external competitiveness constraint, etc., induces innovations that are linked to solutions to social and economic problems: hence, the prevailing industrial specialization in this type of SSIP is health, security, etc. which, actually, can mean a great variety of innovation strategies. In the case of market-based SSIP, Amable (2000) is more restrictive: as this type of SSIP is characterized by highly segmented labour force, decentralization of wage bargaining, and high individual competition, such aspects as knowledge and rapidity are essential in gaining competitive advantage. Therefore, market-based SSIP fosters radical innovations, where patents and individual rewards to innovation are highly important. Nonetheless, even though the scholar envisages the dynamics of the social systems of innovation and production and presents their strengths, weaknesses, conditions for possibility of existence and potential destabilizing factors, and even though he identifies the links with international regime, still, the indefiniteness (i.e. generality) of institutional constituent and, more significantly, the narrowness of the delineation of innovation strategy remain.

\subsubsection{Institutions vs. sectors in facet of innovation strategy of firm}

In order to ascertain if national institutional environment is the most decisive factor determining the character of innovation strategy of a firm originating in that particular national institutional environment, it is necessary to intersect the institutionalist approach towards innovations with the organizational one. Among the notions supporting the organizational approach, the strongest is that of sectoral systems (Malerba 2002). Despite the recognition of the significance of national institutions, the proponents of the institutionalist approach admit that there are important differences among industries in the operation of innovation-related processes (Fagerberg et al. 2009). The sectoral composition of a given national economy influences the motion and structure of its national innovation system, even though the national innovation system affects the operation of its constituent sectoral systems. "Hence, the relationship between sectoral and national innovation systems is a co-evolutionary one [...]" (Fagerberg et al. 2009).

In the previous subchapter, we have revealed how social-democratic SSIP relates to health and security sectors, and market-based SSIP, due to its radical-technological orientation, to aerospace, pharmaceuticals, finance, etc. (Amable 2010). Then, meso-corporatist SSIP is 
based on principles of solidarity and mobility within a large size economic unit (corporation) with diversified production. Here, research is predominantly in-house, tacit knowledge is important, and homogenized general education is needed, while specific skills are developed within the corporation. The financial system of meso-corporatist SSIP is characterized by strong long-term relationships and strong involvement of public authorities. Hence, in meso-corporatist SSIP, sectors, where coordination is necessary and where competence is localized and cumulative, progress: automobile, electronics, robotics. The remaining type of SSIP is the public one, which can shortly be defined as strongly-coordinated capitalism: public basic research is disconnected from development of new products, strong institutionalization of employment rules and social protection, importance of banks, slow adaptation to market changes. Under the conditions of public SSIP, incremental, quality innovation is most likely to emerge, and sectors are linked to public infrastructures and skilled labour force: aerospace, mechanics, automobile. Nonetheless, Amable's (2000) input lacks empirical evidence, which is impeded by the difficulty in distinguishing between different types of SSIP, as they lack geographical dimension and are always subject to institutional complementarity, which overcomes national and industrial borders.

Probably the most elaborated theoretical approach, which reveals the interaction between national institutional and sectoral environment, is that of global production and innovation networks (Lane 2008). The approach passes through the process of relatively early development. According to it, innovation is neither wholly path-dependent, nor is global leverage invariably disruptive of national institutional complementarities. "Because global spaces are still anchored to national territories, institutional constraints have been loosened, but not abandoned" (Lane 2008). Hence, the degree, to which domestic institutional environment conditions innovation strategies of firms, varies according to industry. Conceivably, the variance partly explains the findings of Frenz and Lambert's (2010) research, which, despite integration of a number of characteristics of innovation (e.g. level of uncertainty, source of knowledge, etc.) beyond the extent to which product qualities are differentiated, failed groping any significant embeddedness at neither country nor sector level, except for technological and patent modes of innovation.

This is precisely the reason for why this paper attempts to look for the patterns of institutional and sectoral embeddedness at the level of elements of innovation strategy, and not at the level of types of innovation strategies, as Frenz and Lambert did (2010). Still, the typologies of innovation strategies are presented in the chapter below, and they are incorporated in the empirical survey of this paper. Nonetheless, the paper differs from the previous extensive research as well, which, yes, explored the patterns at the level of elements of innovation strategy (characteristics of innovation) alike, but while doing so, the characteristics were separated from each other and did not form the integrated concept of innovation strategy, which was the driver of this paper and is presented in the next chapter.

\subsection{Conceptual framework of innovation strategy of firm}

Innovation-related literature has largely remained conceptually frozen around the ideas of radical vs. incremental and product vs. process. Obviously, these dichotomies are not sufficient enough to be referred to as innovation strategies. Unfortunately, they often are, and the re- 
search has mainly endured fragmented as sensitive to current external circumstances as well (Tvaronavičienè et al. 2009). Therefore, this paper relies on an integrated conceptual framework of innovation strategy (Stankevice, Jucevicius 2010). Reasoning behind the framework is as following: radical vs. incremental, product vs. process, open vs. secretive, novelty vs. imitation, etc. do not form a versatile comprehension of a strategy. Hence, these types of innovation and characteristics of innovation need to be structurally and purposively interconnected.

The methodology for the composition of the framework rests on the application of the conceptual model of strategy, developed by Hambrick and Fredrickson (2005) within the area of general strategic management, to relevant studies on innovation. The framework, as well the original model, is comprised of five elements: 1) the varieties of possibilities about what to innovate, i.e. object of innovation (e.g. product, process, organization); 2) how to enable innovation, i.e. vehicles of innovation (importance of networks (Fagerberg et al. 2009), partners (Radziszewska-Zielina 2010) and level of openness should be taken into account); 3) speed (e.g. incremental, radical, revolutionary) and scope (e.g. novelty, modification, imitation) of innovation; 4 ) how to bring innovation to target customers (e.g. traditional vs. innovative marketing, low-end vs. high-end users); 5) the fifth element represents the general logic of an innovation strategy and ensures the viability of the link between all the elements, as well as between the objectives and the content of the innovation strategy, and between the innovation strategy and the respective general strategy. Let us consider each of the elements separately, based on our previous research (Stankevice, Jucevicius 2010). While doing so, a number of typologies of innovation strategies are presented.

\subsubsection{Object of innovation}

Hambrick and Fredrickson (2005) identify arenas by asking: "Where will we be active?" They suggest also supporting questions which apply to decisions about product categories, technologies, geographic areas, markets and value-creation stages. If to convert the original question into a question about innovation, one would ask: "Where will we innovate?" Three answers have been derived from relevant classifications applied to innovations in scientific literature. The distinction between product technology and production technology is well known. The former type can be defined as knowledge about how to create or improve products, and the latter as knowledge about how to produce them. Similarly, the terms product innovation and process innovation have been used to characterize the occurrence of new or improved goods or services, and improvements in the ways to produce these goods and services, respectively. In the literature, it is also suggested dividing the category of process innovation into technological process innovations and organizational process innovations, the former related to new types of machinery, and the latter to new ways to organize work. Thus, we get three categories: product, process, and organization.

\subsubsection{Vehicles}

The second part of the concept of strategy is, according to Hambrick and Fredrickson (2005), vehicles, and is defined by the question: "How will we get there?" The suggested answers include internal development, joint ventures, licensing/franchising and acquisitions. If to convert the main question into a question of innovation strategy, it would sound like: "What will enable us to become/remain innovative?" With no doubt, the answers can be found in the 
academic literature of two major approaches. On the one side, system perspective is relevant. The defining characteristics of a system of innovation require that its components are connected for different invention and innovation purposes. In a healthy economy, there would be a good number of specialized innovation systems generated at the microlevel, "systems that are born and decay as new innovation problems are posed and solved" (Foray 2009). On the other side, the answers are also linked with the resource-based view of a firm, which stresses the relevance of resources (both internal and external, both human and material) for an innovation strategy (Whitley 2000). Hence, a company's innovative capacity is central. In addition to internal resources of a company (including its absorptive capacity), networks advantage its innovative capacity through the revelation of new resources and knowledge dissemination. Accordingly, two major criteria for defining vehicles in the concept of an innovation strategy can be distinguished: level of openness in regard to new resources, and level of uncertainty in regard to knowledge dissemination.

As to the level of openness, Visser and Atzema (2007) propose three types of innovation strategies. The stand-alone innovation strategy is characterized by internal sources of knowledge. The local buzz innovation strategy draws necessary knowledge from external local resources. Finally, the global pipeline strategy uses knowledge from multiple globally external resources. Similarly, Srivastava (2006) leans on differences between national, European and global R\&D approaches (and national, European and global innovation policies) in Switzerland, and indicates three innovation strategies within telecommunications' sector, respectively: secretive innovation strategy, cautious innovation strategy and sharing innovation strategy. The first strategy is defined by single relationship, integrated value chain between terminal equipment and incumbent telecom operator, $100 \%$ government ownership, monopoly, as well as control, build and develop principles in R\&D (100\%). The second strategy reflects a higher level of openness: multilateral collaboration along the value chain, disintegrated value chain, progressive "regulated" competition, more than $50 \%$ government ownership, build and buy in $\mathrm{R} \& \mathrm{D}$ (50\%). Finally, the third strategy is characterized by global partnerships and $\mathrm{R} \& \mathrm{D}$ hubs, converging value chain within the industry, competitive market, less than 30\% government ownership, partnerships and outsourcing in R\&D. What is also important within the framework of this paper is Srivastava's (2006) attempt to establish connections between the two elements of the concept of innovation strategy - arenas and vehicles. She ties in secretive innovation strategy with product innovation model, cautious innovation strategy with process innovation model across the value chain, and sharing innovation strategy with business innovation model, or organizational innovation. This fact confirms that, regardless of what the object of analysis is - either general strategy or innovation strategy, - the elements in the model must anyway demonstrate a sufficient interplay.

\subsubsection{Speed and scope}

The third component of the concept of a strategy is staging which is defined by the following question: "What will be our speed and sequence of move?" (Hambrick, Fredrickson 2005). If we convert the main question to "what will the speed and scope of innovation be?", literature on innovations provides us with a couple of sequences of the possible answers: from incremental to revolutionary/disruptive, and from novelty to imitation (Stankevice, Jucevicius 2010). 
A common dichotomy distinguishes radical and incremental innovation. Incremental innovations are improvements of existing products, processes or services, within the context of a dominant design, product architecture or existing demand. Radical innovations, on the other hand, involve a radical break from existing products and processes and often open up new industries and new markets. Radical and incremental innovations can be seen as extreme archetypes, but in practice it may be difficult to distinguish them. Often a distinction can only be made ex-post, since the impact that an innovation has on the economic system generally cannot be known ex-ante, and since all innovations, even radical ones, build to some extent on the existing knowledge base. Some scholars distinguish revolutionary innovations as a separate category. These consist of a cluster of innovations which together have a very far reaching impact (Fagerberg et al. 2009).

\subsubsection{Differentiators}

The fourth element of the concept of a strategy is differentiators, and the authors (Hambrick, Fredrickson 2005) ask: "How will we win - by image, customization, price, styling, or product reliability?" With regard to innovation strategy, the question is: "How will we bring our innovation to our customers?" In this case, it is a question of marketing. The latter depends heavily on the objectives of the innovation strategy, as well as its elements. On the other hand, innovative marketing solutions can be a core of an innovation strategy themselves, but, again, this might imply innovations in process, organization or technology, as well as alter the inter-organisational governance structure and/or the level of the company's openness.

\subsubsection{General logic}

Finally, the last element of the conceptual model of a strategy is general economic logic (Hambrick, Fredrickson 2005). In the context of innovation strategy, the general logic ties together the four other components of the innovation strategy and the strategy's objectives. Moreover, general logic secures the meaningful link between a general strategy and a corresponding innovation strategy. Hence, innovation strategy of a firm should be understood as a central, integrated, externally oriented concept of how a firm will achieve its goals of innovative activity. This comprehension of innovation strategy is strongly supported by the recently emerging approach towards identifying integrated, and not fragmented, concept of innovation (Frenz, Lambert 2010; Battisti, Stoneman 2010). In fact, as it follows from the explored literature, the choice of innovation strategy for a firm depends on many factors, including national institutions, industry policy, internal resources, organizational culture, etc. However, this paper covers the question of national institutional vs. sectoral embeddedness only, without taking into account other factors, even though important as well.

With this statement we do also accept the fact that both the institutional context and industrial environment of a firm are multi-dimensional variables that are characterized by a number of links with the factors which are not investigated in this paper, as well as by a number of inter-links between the two critical variables. The sectoral composition of a given economy influences the motion and structure of its national institutional setting, even though the national institutional setting affects the operation of its constituent sectoral systems. Hence, the relationship between institutional and sectoral cannot be considered completely hierarchical; instead, it is co-evolutionary (Fagerberg et al. 2009). Without doubt, the two 
critical factors of the paper are inter-related, but whereas a part of innovation strategy of a firm is more classed by its institutional environment, the other part falls under the greater influence of its industrial environment. In the paper, it is revealed which elements of innovation strategy of a firm are associated with the sectoral dimension, and which ones - with the institutional context, though the overlap, due to the co-evolutionary nature of the relationship between institutional and sectoral, cannot be denied either.

\section{Methodology}

\subsection{Preparatory stage: two dimensions of the sample}

The sample stands for two different sectors: two service firms (contact centres) and two hightech firms (laser producers). The sectors are different in innovation management, and industry policy is different even in the same country. This is precisely the reason of the choice: we need an intersection - an intersection of sectors within a country and an intersection of countries within a sector. According to the explored literature, contact centres would typically represent incremental, process innovations, and laser producers - radical, product innovations; the literature suggests also that the sectors would have different innovation management policies, different structures of networking, different marketing policies, etc., i.e. everything which precisely is dictated by the aim of the paper.

The sample represents two different market economies as well - Swiss and Lithuanian. Both countries are European market economies and democratic republics, they are relatively small and surrounded by a number of neighbours, among which one would find vastly influential ones. However, the countries contrast sharply with each other due to the dramatically unlike historical paths. After 1990, the transition process in Lithuania has generated an institutional vacuum, and new institutions needed to be introduced. Therefore, the presumption, that the level of incompatibility between formal and informal institutions (Rolfstam 2009) is high in Lithuania, is sound. On the contrary, Switzerland is the oldest democratic republic in Europe distinguished for its stability and political neutrality. Therefore, incompatibility between formal and informal institutions in Switzerland is presumably small or absent. Given the topic of the article, one more distinction is essential: according to Summary Innovation Index, innovation performance is one of the best in Switzerland, whereas Lithuania is steadily somewhere in the end. Hence, commonalities and differences of the countries, described in this paragraph, serve as a basis of the choice of Lithuania and Switzerland. Admittedly, the possibility for the Lithuanian authors to perform the research in precisely Switzerland played its role as well.

However, for reliability's sake, the sample national institutional environments were compared empirically in order to validate their statistical discrepancy. The data provided by the International Profiles Database 2009 was divided into four sections in accordance with the sectors of the database (Crombrugghe et al. 2009):

- public institutions and civil society $(\mathrm{N}=191$ variables $)$;

- market for goods and services $(\mathrm{N}=81$ variables);

- capital market $(\mathrm{N}=45$ variables);

- labour market and social relations $(\mathrm{N}=51$ variable $)$. 
Then, the data was analysed with PASW Statistics 17.0. To measure correlations between the variables in the four groups, Kendall's tau_b coefficient was used because the data were ordinal (Crombrugghe et al. 2009). The results are demonstrated in Table 1. A reader should note that in this table, we compare Lithuanian and Swiss national institutional environments, and not innovation strategies of the sample companies. Hence, for Table 1 the data from IPD 2009 (the database is described in subchapter 1.1.1. in more detail) is used, and not the data, which was collected from the four top-managers. This step of analysis is required because, prior to comparing the innovation strategies, we need to compare the countries statistically in order to confirm that the countries' institutional profiles are really, not presumably (theorizing-based), different - in this paper, we need different institutional profiles in order to guarantee the intersection of countries and sectors.

Difference-between-samples tests were carried out as well, as a confirmatory tool. The results are shown in Table 2. Again, we used the data of the IPD 2009, which describes institutional profiles of countries via 368 variables, and not the data, assessed due to the responses of the top-managers of the four sample firms, as we compare institutional profiles here, and not the innovation strategies (preparatory stage). This step of analysis was required in order to confirm the results, which are presented in Table 1 - in applied statistics, confirmatory analyses are typically more than welcome, especially in social sciences.

\subsection{Methodology for comparing the sample innovation strategies}

In order to analyse the intersection of national institutions with sectoral environment in the most advantageous way, one needs to reduce the impact of other potentially disruptive factors to a minimum. Therefore, the sample firms resembled each other in terms of formal characteristics, such as the year of establishment, number of employees, global presence, average annual turnover, average turnover invested in innovation-related activities, global market share in selling specific innovative products.

A top-manager of each sample firm was interviewed, hence, the number of the interviewed top-managers equals four. Three top-level managers of the companies filled in questionnaires which they had previously received by-email. The fourth manager preferred a structured face-to-face interview to other means of contribution. The research instrument involved 36 questions in total, regarding: 1) innovation strategy; 2) factors influencing the structure of innovation strategy; 3) general information and performance. Representatives of the sample companies had to provide relative percentages from $0 \%=$ "Not true at all" to $100 \%=$ "Completely true" in integral numbers only. The 36 questions were composite/complex, therefore, when they had been decomposed, they converted into 334 simple questions and corresponded to 334 cases in the software $(\mathrm{N}=334: \mathrm{N}=285$ - innovation strategy, $\mathrm{N}=44$ - factors influencing innovation strategy, $\mathrm{N}=5$ - performance), while the sample companies stood for variables, that is, the four firms (variables) were compared along 334 characteristics of innovation strategy.

The data became subject to correlation analyses, difference-between-samples tests were carried out as a confirmatory method. The correlation analyses were required in order to indicate if the correlations between firms from same country, but different sectors were 
greater or smaller than the opposite. This let us verify the hypothesis if national institutional environment was fateful factor determining the structure of innovation strategies of the investigated firms. And again, because methods of applied statistics require confirmation, especially in social sciences, we carried out difference-between-samples tests. The results of both correlation analyses and the difference-between-samples tests are shown in Table 4. It is important to note that our analysis can be defined as a comparative analysis of four case studies, which are supplemented by the statistical analysis of some elements of the cases. By emphasizing this, we address the question of the reliability of the results, when only four firms are investigated. In fact, what are analysed statistically are 368 variables of IPD 2009 and 334 features of an innovation strategy. Thus, the statistical analysis is reliable with regard to the sample sizes. Then, the results along the four sample firms are compared qualitatively. Now, is a case study reliable? For some reasons, it is an important part of both research and teaching. Hereby the comparative analysis of four cases is even more reliable than a case study taken alone.

We have not discussed the Table 3 yet. Why was this step of analysis required? The clue is that both correlation analysis and difference-between-samples test can be based on a number of measures: for example, Pearson correlation or Spearman correlation, Student-t criterion or Wilcoxon? In order to get the answer, one not only need to evaluate the data (e.g. if it is integral, nominal or ordinal), but the sample as a whole as well - if it is compatible with normal distribution or not, because in every case different equations are used by the software. For this reason, we had to perform the analyses, the results of which are presented in Table 3. A reader should also note that we performed the same actions with the data from IPD 2009 (the data about institutional profiles of the countries); however, we presented the results in text, without including a table, because the analysis of the institutional data was needed as a preparatory stage, which just confirms the statistical difference between Lithuanian and Swiss institutions.

Now, let us go back to the data on the innovation strategies and explain the origin of Table 5. In order to highlight the most important elements of innovation strategy in respect of the sample firms, hierarchical cluster analysis with four final solutions was employed. Ward's method was used, and Squared Euclidian Distance was used to measure the differences. For the cluster analysis, the answers of the respondents were used, and according to these answers, each of the 334 cases was assigned (by the software) to one of the 4 clusters, which emerged. The number of clusters corresponds to the number of investigated firms, for each of the firms represents a unique combination of institutional-sectoral intersection and has a unique innovation strategy, which is defined by a certain combination of characteristics of innovation activities (answers to the questions about innovation strategies). Because the clusters emerged from the answers, provided by the respondents, the results are entitled clusters by answers. On the other hand, each of the cases is defined by a certain question, which originated from the explored scientific literature. The authors have already pointed out that the questionnaire included 36 complex questions, which were decomposed and formed 334 simple questions, i.e. cases. Thus, each of the cases corresponds to a certain complex question, and cases which correspond to the same complex question, form a cluster by questions (the variable of questions). 
Because both the variable of questions and clusters by answers are nominal variables, their interrelation can only be verified by sign independence analysis, i.e. cross-tabulation, and the variable of questions and the variable of the saved clusters were cross-tabulated. However, independence hypothesis could not be verified because $91.7 \%$ of the cells counted less than 5 . Still, Cramer V coefficient was used to measure the relationship between the variables. The observed counts let to indicate the most decisive questions, i.e. those which had a bigger count in one specific cluster than in the other ones; in other words, questions, where the greatest interdependence between questions and clusters by answers was identified, were distinguished as the most decisive. Finally, the four innovation strategies were qualitatively compared along these questions, thus resulting in the emergence of Table 5.

\section{Findings}

\subsection{Comparing Swiss and Lithuanian national institutional environments: tight results}

The foremost analysis to implement was to assure of the existence of significant difference between Swiss and Lithuanian national institutional environments. The normality of distribution of the variables (Switzerland $=\mathrm{CH}$; Lithuania $=\mathrm{LT}$ ) within each of the four data groups was verified by histograms, normal P-P plots and Kolmogorov-Smirnov tests ( $\mathrm{p}=[0.000 ; 0.010]<\alpha=0.05)$, and appeared to be inconsistent with normal distribution. Table 1 illustrates the results of the tests.

Table 1. Results of Kolmogorov-Smirnov tests

\begin{tabular}{lccccc}
\hline & & $\begin{array}{c}\text { Public institutions } \\
\text { and civil society } \\
(\mathrm{N}=191)\end{array}$ & $\begin{array}{c}\text { Market for goods } \\
\text { and services } \\
(\mathrm{N}=\mathbf{8 1})\end{array}$ & $\begin{array}{c}\text { Capital } \\
\text { market } \\
(\mathrm{N}=\mathbf{4 5})\end{array}$ & $\begin{array}{c}\text { Labour market } \\
\text { and social relations } \\
(\mathrm{N}=\mathbf{5 1})\end{array}$ \\
\hline $\begin{array}{l}\text { Switzerland } \\
(\mathrm{CH})\end{array}$ & $\mathrm{K}-\mathrm{S} \mathrm{Z}$ & 5.607 & 2.031 & 2.222 & 2.447 \\
\cline { 2 - 6 } $\begin{array}{l}\text { Lithuania } \\
\text { (LT) }\end{array}$ & $\mathrm{p}-\mathrm{S} \mathrm{Z}$ & 3.230 & 0.001 & 0.000 & 0.000 \\
\cline { 2 - 6 } & $\mathrm{p}$ & 0.000 & 2.031 & 1.624 & 1.634 \\
\hline
\end{tabular}

Because the distributions were not compatible with normal ones, Wilcoxon signed-rank tests were performed instead of pared Student's t-tests. The Wilcoxon tests confirmed that Swiss and Lithuanian national institutional environments could not be assumed as statistically indifferent despite existing statistically significant correlations (Table 2) within the samples.

Table 2. Correlation analyses and Wilcoxon tests: comparison of Swiss and Lithuanian NIEs

\begin{tabular}{lcccc}
\hline & $\begin{array}{c}\text { Public institutions } \\
\text { and civil society } \\
(\mathrm{N}=191)\end{array}$ & $\begin{array}{c}\text { Market for goods } \\
\text { and services } \\
(\mathrm{N}=\mathbf{8 1})\end{array}$ & $\begin{array}{c}\text { Capital market } \\
(\mathrm{N}=45)\end{array}$ & $\begin{array}{c}\text { Labour market and } \\
\text { social relations } \\
(\mathrm{N}=51)\end{array}$ \\
\hline Wilcoxon $|\mathrm{Z}|$ & 6.958 & 2.600 & 3.252 & 2.822 \\
\hline Wilcoxon $\mathrm{p}$ & 0.000 & 0.009 & 0.001 & 0.005 \\
\hline Kendall's $\mathrm{r}_{\text {tau_b }}$ & $0.403^{\star *}$ & $0.534^{* *}$ & $0.751^{\star *}$ & $0.312^{\star}$ \\
\hline
\end{tabular}

${ }^{\star}$ Correlation is significant at the 0.05 level (2-taled); ${ }^{* \star}$ Correlation is significant at the 0.01 level (2-taled). 
S374 I. Stankevice, G. Jucevicius. Institutional vs. sectoral dimension of innovation strategies of firms

\subsection{National institutional vs. sectoral context: tight results}

In this section, the foremost analysis to implement was to assure of the existence of significant difference between the innovation strategies.

The normality of distribution of the variables (CH_Laser, LT_Laser, CH_Service and LT_Service) was verified by histograms, normal P-P plots and Kolmogorov-Smirnov tests ( $\mathrm{p}=0.000<\alpha=0.05$ ), and appeared to be inconsistent with normal distribution. Table 3 illustrates the results of Kolmogorov-Smirnov tests $(\mathrm{N}=285)$.

Table 3. Kolmogorov-Smirnov test results for the sample companies

\begin{tabular}{lcccc}
\hline & CH_Laser & LT_Laser & CH_Service & LT_Service \\
\hline K-S Z & 3.475 & 2.408 & 8.147 & 5.537 \\
\hline K-S p & 0.000 & 0.000 & 0.000 & 0.000 \\
\hline
\end{tabular}

Because the distributions were not compatible with normal ones, Wilcoxon signed-rank tests were performed instead of pared Student's t-tests. The Wilcoxon tests confirmed that the innovation strategies could not be assumed as statistically indifferent despite existing statistically significant correlations (Table 4) within the samples.

Table 4. Correlation analyses and Wilcoxon tests: comparison of the innovation strategies

\begin{tabular}{lcccccc}
\hline & $\begin{array}{c}\text { LT_Service } \\
\text { CH_Service }\end{array}$ & $\begin{array}{c}\text { CH_Laser } \\
\text { LT_Laser }\end{array}$ & $\begin{array}{c}\text { CH_Laser } \\
\text { CH_Service }\end{array}$ & $\begin{array}{c}\text { LT_Laser } \\
\text { LT_Service }\end{array}$ & $\begin{array}{c}\text { LT_Laser } \\
\text { CH_Service }\end{array}$ & $\begin{array}{c}\text { CH_LT_Service } \\
\text { LT_Ser }\end{array}$ \\
\hline $\mathrm{W}|\mathrm{Z}|$ & 5.420 & 4.805 & 7.719 & 7.126 & 10.404 & 2.917 \\
\hline $\mathrm{W}$ p & 0.000 & 0.000 & 0.000 & 0.000 & 0.000 & 0.004 \\
\hline $\mathrm{r}$ & $0.527^{\star *}$ & $0.327^{\star *}$ & $0.283^{\star *}$ & $0.190^{\star *}$ & $0.177^{\star *}$ & $0.120^{\star}$ \\
\hline $\mathrm{r}_{\mathrm{tau} b \mathrm{~b}}$ & $0.483^{\star *}$ & $0.370^{\star *}$ & $0.222^{\star *}$ & $0.151^{\star *}$ & $0.143^{\star *}$ & 0.078 \\
\hline $\mathrm{r}_{\mathrm{s}}$ & $0.525^{\star *}$ & $0.375^{\star *}$ & $0.260^{\star *}$ & $0.185^{\star *}$ & $0.171^{\star *}$ & 0.096 \\
\hline
\end{tabular}

* Correlation is significant at the 0.05 level (2-taled); ${ }^{\star *}$ Correlation is significant at the 0.01 level (2-taled).

However, it is necessary to amplify that the correlations between the innovation strategies of firms from the same sectors but different countries are bigger than the correlations between the innovation strategies of firms from the same countries but different sectors. This finding can be treated as the following assumption: the national institutional environments are not fateful factors determining the structures of innovation strategies of the investigated firms; rather, the more decisive factors are the sectoral subjections. It is interesting to note that the innovation strategies of the service firms only are characterized by a stronger correlation $(r=0.527>0.5)$, whereas the remaining comparisons point to the existence of the uniqueness of each of the investigated strategies. Naturally, each of the firms represents a unique combination of institutional-sectoral intersection and has a unique innovation strategy, which is defined by a certain combination of characteristics of innovation activities. This is also one of the reasons for why further analysis (see 3.3. and 3.4.) is needed and why only 15 elements of innovation strategy emerged during it (see 3.4.). 


\subsection{Attitudes towards factors which most influence the sample innovation strategies}

Each of the sample managers had a rather unique view of what factors influenced the respective innovation strategy. The representative of the Swiss contact centre indicated networking with clients and Swiss regional innovation system as the most important factors. The service-oriented company's concern with clients is easily understandable, and the firm's gratitude to the regional innovation system can be associated with the Swiss tradition of establishing sectoral and related associations which help to gain knowledge and get into fruitful partnerships, mostly on a regional level.

The representative of the Swiss laser company referred to Swiss political-institutional environment, and Swiss national and regional innovation systems as to positive forces, and to poor access to venture capital as to a negative factor. The manager's position can be explained by the existence of National Centre of Competence in Research Quantum Photonics (NCCR $\mathrm{QP})$. Acting as a network within Switzerland, the Centre's mission is to carry out fundamental research in areas of strategic relevance to science and society, to foster education and training in the field of photonics and to contribute to technology transfer towards industrial partners (National Centre ... 2011). The Swiss laser producer would have hardly survived without the help of NCCR QP with regard to funding, research infrastructure and provision of links to human capital and potential customers. For example, the Centre is under the directorship of a university research institution which allows research groups based at the home institution to network with other teams working throughout Switzerland. The further development of the Swiss laser producer was fostered by an acquisition of a foreign European company which, in turn, acquired one more company - a Swiss one.

The Lithuanian laser company's representative indicated national system of innovation and the company's name and reputation as two factors which have a clearly expressed influence on the firm's innovation strategy. The Lithuanian company's situation is similar to that of the Swiss laser company: it is also a university's spin-off, thus, the university provides the company with the research infrastructure and human capital. With the development of national system of innovation and the inflow of European structural funds, the company has also got a better access to funding resources. However, the Lithuanian specifics are that there was no institution like the Swiss NCCR QP. Therefore, the company's (and its leaders') name and reputation were also of a great importance when establishing industrial networks and commercializing the very first products. Finally, the representative of the Lithuanian contact centre noted the importance of the company's inner resources (financial, material, human and leadership) and openness of business systems globally. The company serves mainly foreign customers; therefore, the openness of global systems is essential to its activities in general. However, almost like in the case of the Lithuanian laser company, the service-oriented firm could not rely on external help in finding customers. The effort was taken by the owner and CEO in order to pull in foreign capital: hence, the success originated from the extensive network of their personal contacts. However, the major obstacle in the company's innovative activities remains the lack of proper external local recourses.

Hence, the Swiss firms can be collated for the infusion of their innovative activities into the broader regional and (or) national context. On the other hand, the laser producer, being 
a high-tech company, was supported by the political-institutional environment more than the contact centre, which alone, due to its performance, is characterized by smaller input into the national economy. Moreover, a contact centre is in less need of venture capital per se. Then, the attitudes of the Lithuanian managers can be paralleled in terms of relatively poor access of the firms to external local resources. Though, again, the laser producer could better make advantage of the opportunities proposed by the national institutional environment. Otherwise, the disparities between the Lithuanian views could be compared to those of the Swiss ones, as arising out of the sectoral specifics. However, in general, each of the managers had a rather individual view of factors which influenced innovation strategies of their firms.

\subsection{The most decisive characteristics and a comparison of the sample innovation strategies along them}

The relationship between clusters by answers and the variable of questions was rather weak (Cramer $\mathrm{V}=0.368$ ) but statistically significant $(\mathrm{p}=0.000<\alpha=0.05)$. This can be explained by an insight that, not by a long shot, all the questions were important in clustering the given answers. The observed counts showed there were 15 questions of a decisive importance. The innovation strategies, as well as the attitudes towards factors influencing them and general information about the companies, were analysed in consonance with the 15 questions (Table 5).

As Table 5 illustrates, the difference-making questions, which are assigned to cluster 1 , describe mostly networking patterns and reveal predominantly sectoral contrasts. Interestingly, company's performance is also included in this cluster. This can probably be explained by an insight that performance can only be groped in comparison - therefore, networks stand for a space which enables evaluation. Characteristics of cluster 2 embrace a number of the elements of innovation strategy and, again, exhibit predominantly sectoral differences. It is worth noting that the cluster is clearly associated with products and/or services: what they are, how they are produced, how they get into markets, etc. In addition, the aim of innovation strategy, which is one of its binding elements, is also included in this cluster.

Unlike the two already discussed clusters, cluster 3 displays national specifics. Cultural informal institutions could account for the different approaches towards R\&D. The Swiss assume that people are basically good, whereas Lithuanians have doubts about the essence of human nature; the Swiss are more publicly-oriented and more collectivist than Lithuanians. Hence, Lithuanians are more reserved and prefer to rely on themselves. These arguments are based on the findings of a study of cultural features of the Swiss and Lithuanians, which included interviews with experts and researchers in the area, who served as evaluators of the cultural specifics in accordance with the model developed by Schneider and Barsoux (2003). On the other hand, Lithuania cannot brag for its extensive network of intermediate institutions, such as Swiss NCCR QP, or Swiss sectoral associations and numerous non-profit organizations (see 3.3.). Therefore, external local sources of knowledge serve for the Swiss companies, whereas the Lithuanian ones rely, again, on themselves and take pleasure in using advantages of globally increasing openness of business systems.

Considering the companies' attitudes towards innovation-related partnerships, only the Lithuanian firms demonstrate correspondence (cluster 4). However, each of the companies 
Table 5. The sample innovation strategies along their characteristics which make most of difference

\begin{tabular}{|c|c|c|c|c|c|}
\hline Cluster & Characteristics & $\mathrm{CH}$ Laser & LT Laser & CH Service & LT Service \\
\hline \multirow{5}{*}{ 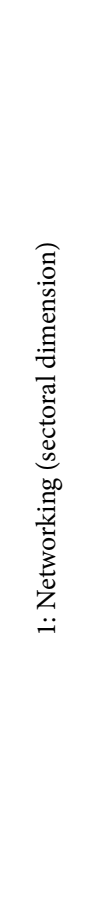 } & $\begin{array}{l}\text { Major networks in } \\
\text { innovation-related } \\
\text { activities (strength } \\
\text { and quantity) }\end{array}$ & $\begin{array}{l}\checkmark \text { Universities } \\
\checkmark \text { Private research } \\
\text { organizations } \\
\checkmark \text { Firms from other } \\
\text { sectors } \\
\sqrt{ } \text { Clients } \\
\checkmark \text { Non-profit } \\
\text { organizations }\end{array}$ & $\begin{array}{l}\checkmark \text { Universities } \\
\sqrt{ } \text { State funded } \\
\text { research institutes } \\
\sqrt{ } \text { Firms from other } \\
\text { sectors } \\
\sqrt{ } \text { Firms from the } \\
\text { same sector }\end{array}$ & $\begin{array}{l}\sqrt{ } \text { Customers } \\
\sqrt{ } \text { Suppliers } \\
\sqrt{ } \text { External } \\
\text { consultants }\end{array}$ & $\begin{array}{l}\checkmark \text { Customers } \\
\checkmark \text { Suppliers } \\
\checkmark \text { Firms from } \\
\text { the same sector } \\
\checkmark \text { External } \\
\text { consultants }\end{array}$ \\
\hline & $\begin{array}{l}\text { Dominating } \\
\text { information- } \\
\text { sharing structure } \\
\text { in networking }\end{array}$ & $\begin{array}{l}\text { Processes and } \\
\text { mechanisms } \\
\text { favour solution } \\
\text { seekers in sourcing } \\
\text { intellectual } \\
\text { property from } \\
\text { external parties }\end{array}$ & $\begin{array}{l}\text { Processes and } \\
\text { mechanisms } \\
\text { favour solution } \\
\text { seekers in sourcing } \\
\text { intellectual } \\
\text { property from } \\
\text { external parties }\end{array}$ & $\begin{array}{l}\text { Varied, can favour } \\
\text { either seekers, } \\
\text { solvers, or both, } \\
\text { depending on the } \\
\text { business model } \\
\text { implemented }\end{array}$ & $\begin{array}{l}\text { Varied, can favour } \\
\text { either seekers, } \\
\text { solvers, or both, } \\
\text { depending on the } \\
\text { business model } \\
\text { implemented }\end{array}$ \\
\hline & $\begin{array}{l}\text { Who specifies } \\
\text { a problem when } \\
\text { looking for } \\
\text { a solution }\end{array}$ & $\begin{array}{l}\text { Seeker specifies } \\
\text { problems }\end{array}$ & $\begin{array}{l}\text { Intermediary helps } \\
\text { solution seekers } \\
\text { specify the problem }\end{array}$ & $\begin{array}{l}\text { Seeker specifies } \\
\text { problems }\end{array}$ & $\begin{array}{l}\text { Seeker specifies } \\
\text { problems }\end{array}$ \\
\hline & $\begin{array}{l}\text { Strength of } \\
\text { relationship } \\
\text { between seeker } \\
\text { and solver }\end{array}$ & $\begin{array}{l}\text { Strong, usually } \\
\text { a medium to } \\
\text { long-term } \\
\text { relationship }\end{array}$ & $\begin{array}{l}\text { Weak or strong, } \\
\text { varies based on } \\
\text { the processes of } \\
\text { the intermediary } \\
\text { involved }\end{array}$ & $\begin{array}{l}\text { Varies from solver } \\
\text { to solver }\end{array}$ & $\begin{array}{l}\text { Varies from solver } \\
\text { to solver }\end{array}$ \\
\hline & $\begin{array}{l}\text { Firm's } \\
\text { performance }\end{array}$ & Successful & Very successful & Very successful & Very successful \\
\hline \multirow{5}{*}{ 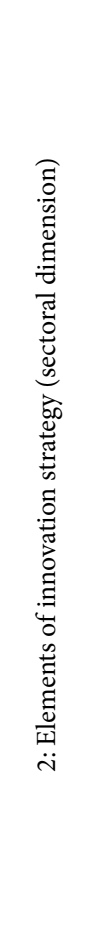 } & $\begin{array}{l}\text { Aim of innovation } \\
\text { strategy }\end{array}$ & $\begin{array}{l}\text { Meet clients' needs } \\
\text { and maintain } \\
\text { existing positions } \\
\text { by intensively } \\
\text { offering new } \\
\text { products and } \\
\text { slightly modifying } \\
\text { existing ones }\end{array}$ & $\begin{array}{l}\text { Maintain existing } \\
\text { positions by } \\
\text { intensively offering } \\
\text { new products and } \\
\text { slightly modifying } \\
\text { existing ones }\end{array}$ & $\begin{array}{l}\text { Maintain existing } \\
\text { positions by } \\
\text { mostly modifying } \\
\text { existing products }\end{array}$ & $\begin{array}{l}\text { Maintain existing } \\
\text { positions by both } \\
\text { offering new } \\
\text { products/services } \\
\text { and modifying } \\
\text { existing ones }\end{array}$ \\
\hline & What is innovated & $\begin{array}{l}\text { Mainly products } \\
\text { and organization } \\
\text { of work }\end{array}$ & $\begin{array}{l}\text { Mainly products } \\
\text { and processes }\end{array}$ & $\begin{array}{l}\text { Organization } \\
\text { of work and } \\
\text { processes }\end{array}$ & $\begin{array}{l}\text { Organization } \\
\text { of work and } \\
\text { processes }\end{array}$ \\
\hline & $\begin{array}{l}\text { Level of novelty } \\
\text { in innovations }\end{array}$ & $\begin{array}{l}\text { Completely new } \\
\text { products; some } \\
\text { modifications }\end{array}$ & $\begin{array}{l}\text { Predominantly new } \\
\text { products, some } \\
\text { modifications }\end{array}$ & $\begin{array}{l}\text { Modifications and } \\
\text { imitations }\end{array}$ & $\begin{array}{l}\text { Modifications and } \\
\text { imitations, some } \\
\text { novelty }\end{array}$ \\
\hline & $\begin{array}{l}\text { Ways of bringing } \\
\text { products/services } \\
\text { to markets }\end{array}$ & $\begin{array}{l}\text { Predominantly } \\
\text { based on existing } \\
\text { external local } \\
\text { networks }\end{array}$ & $\begin{array}{l}\text { Based on existing } \\
\text { external networks } \\
\text { and personal } \\
\text { contacts of leaders }\end{array}$ & $\begin{array}{l}\text { Predominantly } \\
\text { based on personal } \\
\text { contacts of } \\
\text { leaders, some } \\
\text { traditional } \\
\text { marketing }\end{array}$ & $\begin{array}{l}\text { Predominantly } \\
\text { based on existing } \\
\text { external local } \\
\text { networks, some } \\
\text { traditional } \\
\text { marketing }\end{array}$ \\
\hline & $\begin{array}{l}\text { Collaborative } \\
\text { arrangements }\end{array}$ & $\begin{array}{l}\text { Mainly multilateral } \\
\text { collaboration along } \\
\text { the value chain }\end{array}$ & $\begin{array}{l}\text { Mainly multilateral } \\
\text { collaboration along } \\
\text { the value chain }\end{array}$ & $\begin{array}{l}\text { Mixed (single } \\
\text { relationship } \\
+ \text { multilateral } \\
\text { collaboration } \\
\text { along the value } \\
\text { chain + global } \\
\text { partnerships) }\end{array}$ & $\begin{array}{l}\text { Mixed (single } \\
\text { relationship } \\
+ \text { global } \\
\text { partnerships) }\end{array}$ \\
\hline
\end{tabular}


Continued Table 5

\begin{tabular}{|c|c|c|c|c|c|}
\hline Cluster & Characteristics & $\mathrm{CH}$ Laser & LT Laser & CH Service & LT Service \\
\hline 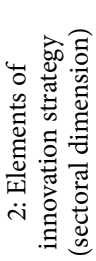 & $\begin{array}{l}\text { Type of value } \\
\text { chain }\end{array}$ & $\begin{array}{l}\text { Disintegrated value } \\
\text { chain (multilateral } \\
\text { collaboration in } \\
\text { the process of value } \\
\text { creation) }\end{array}$ & $\begin{array}{l}\text { Mostly } \\
\text { disintegrated value } \\
\text { chain (multilateral } \\
\text { collaboration in } \\
\text { the process of value } \\
\text { creation) }\end{array}$ & $\begin{array}{l}\text { Mix of integrated } \\
\text { value chain } \\
\text { throughout the } \\
\text { whole process of } \\
\text { value creation and } \\
\text { convergent within } \\
\text { the respective } \\
\text { industry }\end{array}$ & $\begin{array}{l}\text { Mix of integrated } \\
\text { value chain } \\
\text { throughout the } \\
\text { whole process of } \\
\text { value creation and } \\
\text { convergent within } \\
\text { the respective } \\
\text { industry }\end{array}$ \\
\hline \multirow{2}{*}{ 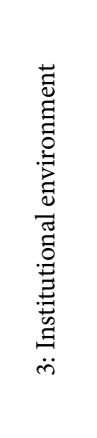 } & $\begin{array}{l}\text { Where knowledge } \\
\text { for innovation } \\
\text { strategy comes } \\
\text { from }\end{array}$ & $\begin{array}{l}\text { Mostly external } \\
\text { local sources of } \\
\text { knowledge }\end{array}$ & $\begin{array}{l}\text { Internal sources } \\
\text { of knowledge and } \\
\text { multiple globally } \\
\text { external sources }\end{array}$ & $\begin{array}{l}\text { Mostly external } \\
\text { local sources of } \\
\text { knowledge }\end{array}$ & $\begin{array}{l}\text { Internal sources } \\
\text { of knowledge and } \\
\text { multiple globally } \\
\text { external sources }\end{array}$ \\
\hline & $\begin{array}{l}\text { Contribution } \\
\text { to external } \\
\text { innovativeness } \\
\text { beyond company's } \\
\text { boundaries }\end{array}$ & $\begin{array}{l}\text { Leading in } \\
\text { contribution } \\
\text { to formation } \\
\text { of new markets } \\
\text { ( } 9 \% \text { of workforce), } \\
\text { creation and } \\
\text { diffusion of new } \\
\text { knowledge, supply } \\
\text { of resources }\end{array}$ & $\begin{array}{l}\text { Leading, esp. in } \\
\text { guidance of the } \\
\text { direction of search, } \\
\text { supply of resources, } \\
\text { creation of positive } \\
\text { external economies }\end{array}$ & $\begin{array}{l}\text { Shaping profile } \\
\text { innovation } \\
\text { strategy }\end{array}$ & $\begin{array}{l}\text { Learning } \\
\text { innovation } \\
\text { strategy }\end{array}$ \\
\hline 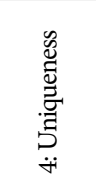 & $\begin{array}{l}\text { Attitudes towards } \\
\text { innovation-related } \\
\text { partnerships }\end{array}$ & $\begin{array}{l}\text { Reduce negative, } \\
\text { avoid difference }\end{array}$ & $\begin{array}{l}\text { Promote positive, } \\
\text { tolerate difference }\end{array}$ & $\begin{array}{l}\text { Promote positive, } \\
\text { avoid difference }\end{array}$ & $\begin{array}{l}\text { Promote positive, } \\
\text { tolerate difference }\end{array}$ \\
\hline
\end{tabular}

Similarities between the two laser companies

Similarities between the two service companies

Neither nationally or sectorally structured similarities

Similarities between the two Swiss companies

Similarities between the two Lithuanian companies

appeared to have mixed relationships, if to measure them in accordance with Fowles' and Clark's (2005) distinction of behaviours of partners. For example, a company can both focus on learning and continuous improvement, and rely on clear communication and confirmed understanding. Thus, the mean positions of the companies in respect of reasons for partnering and view of difference (Fowles, Clark 2005) are unclear. It is difficult to generalize the attitudes in consonance with their either national or sectoral subjection. Inter alia, this is not surprising: since a firm's attitude towards networking partners depends, to some extent, on its both national and sectoral subjection (besides inner factors), the investigated companies act as a spectrum of the possible results originating from the two-by-two intersection (two sets of institutions by two industrial sectors). 


\section{Concluding remarks}

The debate about the role of national institutional environment in shaping the corresponding firms' innovation strategies is highly controversial. Both the proponents of the notion of comparative institutional advantage and their challengers have provided solid argument and evidence to make out their cases. Moreover, the concept of innovation strategy has remained conceptually under-structured within the debate, thus making the comprehension of the interaction between national institutional environment and firms' innovation strategies even more vague and fragile.

In this paper, the significance of national institutional environment to innovation strategy has not been denied. On the contrary, the results show that the lack of an extensive network of intermediate institutions between a firm and national level conditions that the firms, in their search for innovation-related knowledge, rely on their internal sources and multiple globally external sources, whereas the companies, which have access to more generous, in this regard, national institutional environments, can advantage from using external local sources of knowledge. Furthermore, national cultural institutions influence a way in which research and development is managed. When a surrounding culture of a company is more publicly-oriented, more collectivist and more positive about others, it is likely that the mode of research and development is based on outsourcing and partnerships; otherwise, a company prefers to control, build and develop the activities itself.

However, the role of national institutional environment in shaping the respective firms' innovation strategies is not that decisive: the firms' sectoral subjection seems to be more influential hoc sensu. The latter governs a type of a firm's networks in its innovation-related activities: for the high-tech companies, collaboration with universities and different research institutions is essential, whereas the service companies concentrate on clients, suppliers and external consultants. Then, in laser industry, processes and mechanisms predominantly favour solution seekers in sourcing intellectual property from external parties, whereas within the area of activity of the contact centres these processes and mechanisms depend heavily on the implemented business model. Finally, the sectoral subjection is firmly associated with a number of elements of innovation strategy. Thus, the high-tech companies mostly create new products or modify the existing ones in an innovative way, whereas the service companies' innovations take place when refining organization of work or processes. The ways in which innovative products are produced or innovative services are infused differ as well. While the high-tech companies rely on multilateral collaboration in the process of value creation, the service companies bucket inspiration from either their inner sources or, in case of an imitative innovation, convergence of value chain within the respective industry.

Notwithstanding the question of the interaction of national institutional and sectoral environments with firms' innovation strategies remains open for further refinement. This paper covers four statistically and qualitatively explored and compared case studies; therefore, any generalizations should be weighed responsibly. However, in further research, a proper comprehension of innovation strategy, as well as institutional and sectoral environments, is particularly desirable. Neither can innovation strategy be limited to a couple of its elements or characteristics, nor can the environments be squeezed into a couple of formal indicators. 
S380 I. Stankevice, G. Jucevicius. Institutional vs. sectoral dimension of innovation strategies of firms

\section{Acknowledgements}

This paper draws on the project The innovation strategies of organizations in the emerging economic-institutional environment (agreement No. MIP-024/12), sponsored by the Research Council of Lithuania. We would also like to express our deepest gratitude to Prof. Michel Oris for guidance and support, as well as Prof Lucio Baccaro, Prof Susan Schneider and Prof Luc Gauthier during Inga Stankevice's research stay at the University of Geneva in 2011.

\section{References}

Acemoglu, D.; Robinson, J. 2010. The role of institutions in growth and development, Review of Economics and Institutions 1(2): 1-33. http://dx.doi.org/10.5202/rei.v1i2.1

Allen, M. 2004. The varieties-of-capitalism paradigm: not enough variety?, Socio-Economic Review 2(1): 87-108. http://dx.doi.org/10.1093/soceco/2.1.87

Amable, B. 2000. Institutional complementarity and diversity of social systems of innovation and production, Review of International Political Economy 7(4): 645-687.

Battisti, G.; Stoneman, P. 2010. How innovative are UK firms? Evidence from the fourth UK Community Innovation Survey on synergies between technological and organizational innovations, British Journal of Management 21(1): 187-206. http://dx.doi.org/10.1111/j.1467-8551.2009.00629.x

Casper, S. 2009. Can new technology firms succeed in coordinated market economies? A response to Herrmann and Lange, Socio-Economic Review 7(2): 209-215. http://dx.doi.org/10.1093/ser/mwn034

Chaudhry, A.; Garner, Ph. 2007. Do governments suppress growth? Institutions, rent-seeking, and innovation blocking in a model of Schumpeterian growth, Economics \& Politics 19(1): 35-52. http://dx.doi.org/10.1111/j.1468-0343.2007.00301.x

Crombrugghe, D.; Farla, K.; Meisel, N.; Neubourg, Ch.; Aoudia, J. Ou.; Szirmai, A. 2009. Institutional Profiles Database III. Paris: DGTPE. 25 p.

Doloureux, D. 2002. What we should know about regional systems of innovation, Technology in Society 24(3): 243-263. http://dx.doi.org/10.1016/S0160-791X(02)00007-6

Fagerberg, J.; Mowery, D. C.; Verspagen, B. 2009. The evolution of Norway's national innovation system, Science and Public Policy 36(6): 431-444. http://dx.doi.org/10.3152/030234209X460944

Foray, D. 2009. Research, innovation and economic growth: what does really matter?, in CD Proc. of the FutuRIS Conference on Public Support for Innovation: Efficiency and Future Prospects, 1 April 2009, Paris, France, 1-21.

Fowles, F.; Clark, W. 2005. Innovation networks: good ideas from everywhere in the world, Strategy \& Leadership 33(4): 46-50. http://dx.doi.org/10.1108/10878570510608040

Frenz, M.; Lambert, R. 2010. Connected innovation: an international comparative study that identifies mixed modes of innovation, in Proc. of the Conference Opening Up Innovation: Strategy, Organization and Technology (DRUID Summer Conference), 16-18 June, 2010, London, UK, 2-40.

Fromhold-Eisebith, M. 2007. Bridging scales in innovation policies: how to link regional, national and international innovation systems, European Planning Studies 15(2): 217-233. http://dx.doi.org/10.1080/09654310601078754

Fuller, D. B. 2009. China's national system of innovation and uneven technological trajectory: the case of China's integrated circuit design industry, Chinese Management Studies 3(1): 58-74. http://dx.doi.org/10.1108/17506140910946142

Hall, J. C.; Sobel, R. S. 2008. Institutions, entrepreneurship, and regional differences in economic growth, Southern Journal of Entrepreneurship 1(1): 69-96. 
Hall, P.; Soskice, D. 2001. Varieties of capitalism: the institutional foundations of comparative advantage. $1^{\text {st }}$ ed. Oxford University Press. 570 p.

Hambrick, D. C.; Fredrickson, J. W. 2005. Are you sure you have a strategy?, Academy of Management Executive 19(4): 51-62. http://dx.doi.org/10.5465/AME.2005.19417907

Herrmann, A. M. 2008. One political economy, one competitive strategy? Comparing pharmaceutical firms in Germany, Italy, and the UK. $1^{\text {st }}$ ed. Oxford University Press. 256 p.

Hollingsworth, J. R. 2000. Doing institutional analysis: implications for the study of innovations, Review of International Political Economy 7(4): 595-644. http://dx.doi.org/10.1080/096922900750034563

Koen, C. I. 2005. Comparative international management. $1^{\text {st }}$ ed. McGraw-Hill Education. 592 p.

Köhler, H.-D. 2008. Profit and innovation strategies in low-tech firms, Estudios de Economía Aplicada 26(3): 73-87.

Lane, Ch. 2008. National capitalisms and global production networks: an analysis of their interaction in two global industries, Socio-Economic Review 6(2): 227-260. http://dx.doi.org/10.1093/ser/mwm010

Lange, K. 2009. Institutional embeddedness and the strategic leeway of actors: the case of the German therapeutical biotech industry, Socio-Economic Review 7(2): 181-207.

http://dx.doi.org/10.1093/ser/mwn029

Lewin, A. Y.; Volberda, H. W. 2005. The future of organization studies: beyond the selection-adaptation debate, in Tsoukas, H.; Knudsen, Ch. (Eds). Oxford handbook of organization theory: meta-theoretical perspectives. $1^{\text {st }}$ ed. Oxford University Press, 568-595.

Lundvall, B. 1992. National systems of innovation: towards a theory of innovation and interactive learning. Pinter Publishers. 342 p.

Malakauskaite, A.; Navickas, V. 2011. Contribution of clusters to the competitiveness of companies: revelation and evaluation, Inzinerine Ekonomika - Engineering Economics 22(1): 50-57. http://dx.doi.org/10.5755/j01.ee.22.1.218

Malerba, F. 2002. Sectoral systems of innovation and production, Research Policy 31(2): 247-264. http://dx.doi.org/10.1016/S0048-7333(01)00139-1

National Centre of Competence in Research Quantum Photonics (NCCR QP). 2011. About us [online], [cited 17 January 2011]. Available from Internet: http://nccr-qp.epfl.ch/page20202.html

Radziszewska-Zielina, E. 2010. Analysis of the partnering relations of Polish, Slovak and Ukrainian construction enterprises, Technological and Economic Development of Economy 16(3): 432-454. http://dx.doi.org/10.3846/tede.2010.27

Redding, G. 2005. The thick description and comparison of societal systems of capitalism, Journal of International Business Studies 36(2): 123-155.

Rolfstam, M. 2009. Public procurement as an innovation policy tool: the role of institutions, Science and Public Policy 36(5): 349-360. http://dx.doi.org/10.3152/030234209X442025

Schneiberg, M. 2007. What's on the path? Path dependence, organizational diversity and the problem of institutional change in the US economy, 1900-1950, Socio-Economic Review 5(1): 47-80. http://dx.doi.org/10.1093/ser/mwl006

Schneider, S. C.; Barsoux, J.-L. 2003. Managing across cultures. $2^{\text {nd }}$ ed. Prentice Hall, Financial Times. 352 p.

Srivastava, J. V. 2006. Incumbent firms' innovation strategies and organizational restructuring during industry deregulation and technological change, in CD Proc. of the 15th International Conference on Management of Technology (IAMOT-2006), 22-26 May, 2006, Beijing, China, 1-8.

Stankevice, I.; Jucevicius, G. 2010. Innovation strategy: an integrated theoretical framework, Social Sciences 3(69): 24-31.

Thomsen, J. 2008. Processes of localization and institutionalization of local managers in economic functions in Danish owned subsidiaries in Estonia, Latvia and Lithuania around the 21st century, Journal of Business Economics and Management 9(4): 279-287. http://dx.doi.org/10.3846/1611-1699.2008.9.279-287 
S382 I. Stankevice, G. Jucevicius. Institutional vs. sectoral dimension of innovation strategies of firms

Tvaronavičienė, M.; Grybaitė, V.; Tvaronavičienė, A. 2009. If institutional performance matters: development comparisons of Lithuania, Latvia and Estonia, Journal of Business Economics and Management 10(3): 271-278.

Visser, A.-J.; Atzema, Oe. 2007. With or without clusters: facilitating innovation through a differentiated and combined network approach, European Planning Studies 16(9): 1169-1188. http://dx.doi.org/10.1080/09654310802401573

Whitley, R. 2000. The institutional structuring of innovation strategies: business systems, firm types and patterns of technical change in different market economies, Organization Studies 21(5): 855-886. http://dx.doi.org/10.1177/0170840600215002

Inga STANKEVICE. Researcher, Nottingham University Business School, University of Nottingham. $\mathrm{PhD}$ candidate in Social Science (management and administration), Kaunas University of Technology. She has 8 scientific awards, she is a member of international scientific DRUID Society. Research interests include comparative political and social economics, innovation strategy, future forms of economies and businesses, research methodology.

Giedrius JUCEVICIUS. Professor, Doctor of Social Science (management and administration), Head of the Department of Strategic Management, Kaunas University of Technology. Author and co-author of $\sim 10$ books, has more than 40 publications. Research interests include comparative international management, innovations, networks and collective learning, transformations of culture, institutions and values. 